\section{PELAKSANAAN}

QARDHUL HASAN

DALAM PENDISTRIBUSIAN ZAKAT

DI BAITUL QIRADH BAZNAS

Buku ini membahas tentang:

1. Bagaimana pelaksanaan qardhul hasan dalam pendistribusian zakat di Baitul Qiradh BAZNAS dan

2. Bagaimana tinjauan hukum ekonomi syariah terhadap pelaksaan qardhul hasan pada Baitul Qiradh BAZNAS tersebut.

Isi buku ini mengandung pandangan serta pemikiran yang diambil oleh para ahli. Bukan hanya satu, namun pendapat beberapa pakar ahli dirangkum di dalamnya. Buku ini memberikan informasi yang lebih detail tentang bagaimana cara memahami konsep pelaksanaan qardhul hasan dalam pendistribusian zakat dan tinjauan hukum ekonomi syariah terhadap pelaksaan qardhul hasan pada Baitul Qiradh secara lebih terstruktur. Sehingga buku ini sangat cocok bagi kalangan mahasiswa.

Buku ini sangat jauh dari kesempurnaan maka dengan senang hati penulis menerima saran dan kritikan yang membangun dari pembaca.

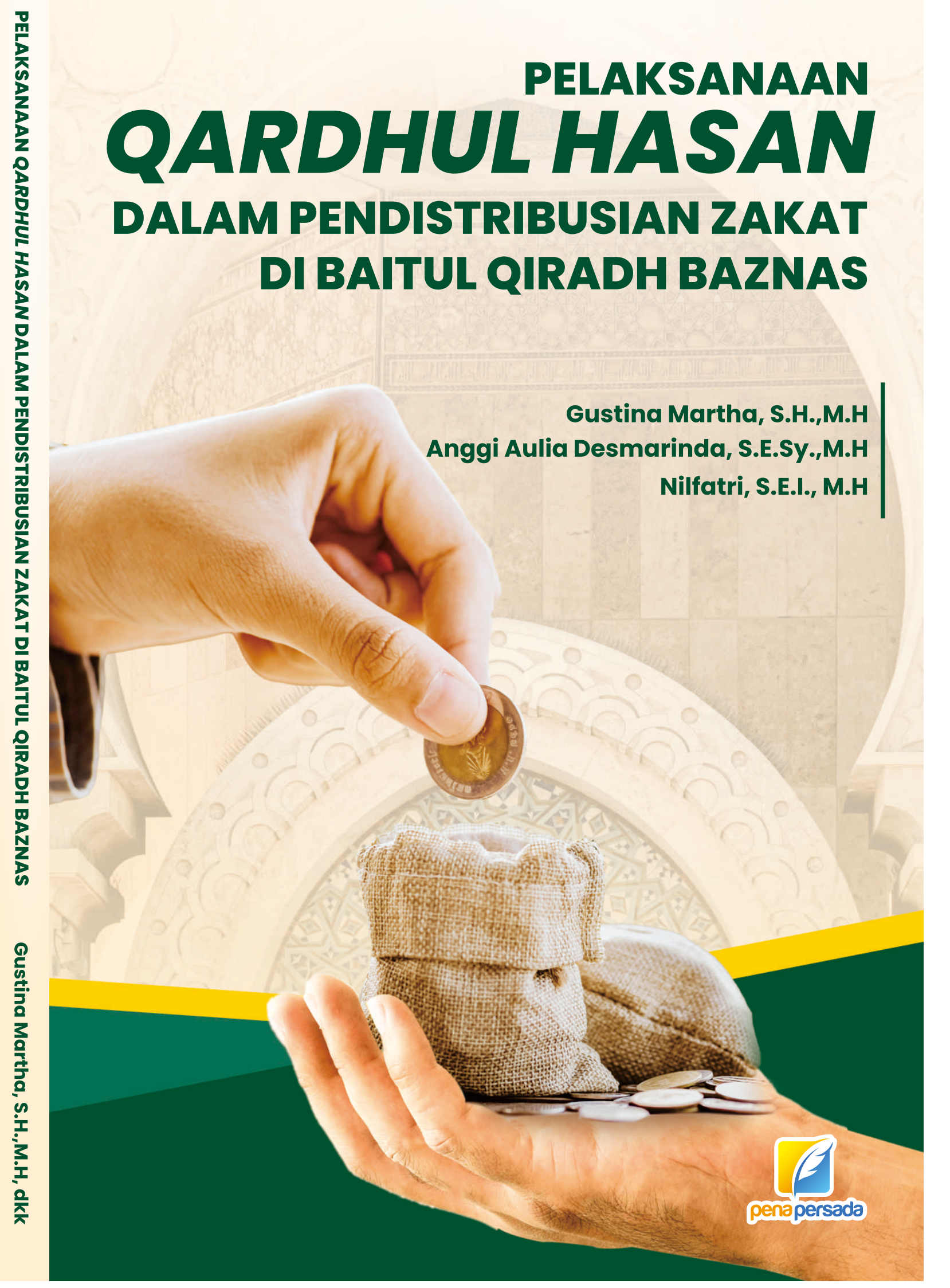




\title{
PELAKSANAAN QARDHUL HASAN DALAM PENDISTRIBUSIAN ZAKAT DI BAITUL QIRADH BAZNAS
}

\author{
Gustina Martha, S.H., M.H, \\ Nilfatri, S.E.I., M.H
}

Anggi Aulia Desmarinda, S.E.Sy., M.H

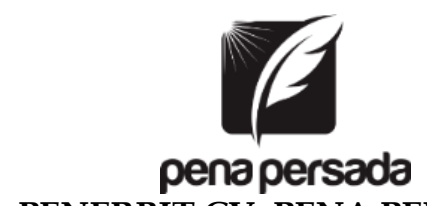

PENERBIT CV. PENA PERSADA 


\title{
PELAKSANAAN QARDHUL HASAN DALAM PENDISTRIBUSIAN ZAKAT DI BAITUL QIRADH BAZNAS
}

\author{
Penulis: \\ Gustina Martha, S.H., M.H, \\ Nilfatri, S.E.I., M.H \\ Anggi Aulia Desmarinda, S.E.Sy., M.H \\ ISBN : 978-623-315-221-1 \\ Editor: \\ Alisyah Pitri, M.Pd \\ Design Cover : \\ Retnani Nur Briliant \\ Layout : \\ Nisa Falahia

\section{Penerbit CV. Pena Persada} \\ Redaksi : \\ Jl. Gerilya No. 292 Purwokerto Selatan, Kab. Banyumas \\ Jawa Tengah \\ Email : penerbit.penapersada@gmail.com \\ Website : penapersada.com Phone : (0281) 7771388

\section{Anggota IKAPI} \\ All right reserved \\ Cetakan pertama : 2021
}

Hak Cipta dilindungi oleh undang-undang. Dilarang memperbanyak karya tulis ini dalam bentuk apapun tanpa izin penerbit 


\section{KATA PENGANTAR}

Puji syukur saya panjatkan kepada Tuhan Yang Maha Esa, karena atas berkat dan rahmat-Nya, saya dapat menyelesaikan buku ini. Penulisan buku merupakan buah karya dari pemikiran penulis yang diberi judul "Pelaksanaan Qardhul hasan Dalam Pendistribusian Zakat Di Baitul Qiradh BAZNAS" Saya menyadari bahwa tanpa bantuan dan bimbingan dari berbagai pihak sangatlah sulit bagi saya untuk menyelesaikan karya ini. Oleh karena itu, saya mengucapkan banyak terima kasih pada semua pihak yang telah membantu penyusunan buku ini. Sehingga buku ini bisa hadir di hadapan pembaca.

Kajian dalam buku ini bertujuan untuk mengetahui pelaksanaan qardhul hasan dalam pendistribusian zakat di Baitul Qiradh BAZNAS. Serta untuk mengetahui tinjauan hukum ekonomi syariah terhadap pelaksanaan qardhul hasan dalam pendistribusian zakat di Baitul Qiradh BAZNAS. Qardhul hasan Yaitu Pinjaman kebajikan yang diberikan oleh Baitul Qiradh BAZNAS selaku sahibul mal (pemilik harta) kepada Mustahiq yang memerlukan dana jangka pendek baik untuk keperluan bersifat konsumtif ataupun keperluan bersifat produktif (modal usaha).

Kajian ini diharapkan mampu menjadi tambahan dan media pembanding dalam khazanah keilmuan di bidang muamalah, khususnya berkaitan dengan perkembangan pemikiran Islam dalam hal transaksi Qordhul Hasan.

Penulis menyadari bahwa buku ini masih jauh dari kesempurnaan. Oleh karena itu kritik dan saran yang membangun sangat dibutuhkan guna penyempurnaan buku ini. Akhir kata saya berharap Tuhan Yang Maha Esa berkenan membalas segala kebaikan semua pihak yang telah membantu. Semoga buku ini akan membawa manfaat bagi pengembangan ilmu di bidang muamalah. 


\section{DAFTAR ISI}

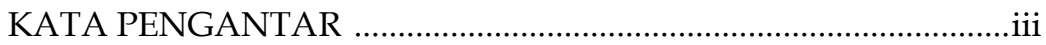

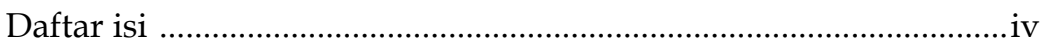

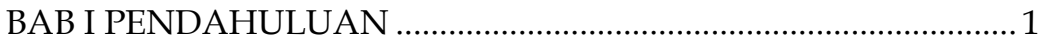

A. Kewajiban Zakat dalam Islam ................................................. 1

B. Gambaran Umum BAZNAS Provinsi Sumatera Selatan ....... 5

1. Sejarah Berdirinya BAZNAS Prov. Sumatera Selatan .......5

2. Fungsi dan Tugas Pokok BAZNAS Provinsi Sumatera

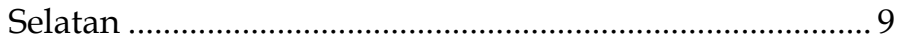

3. Visi dan Misi BAZNAS Provinsi Sumatera Selatan ......... 10

4. Tujuan, Sasaran dan Asas Pengelolaan................................ 11

5. Strategi Badan Amil Zakat Nasional (BAZNAS) Sumatera Selatan............................................................. 13

6. Program Kerja Bagian dan Bidang-Bidang ...................... 14

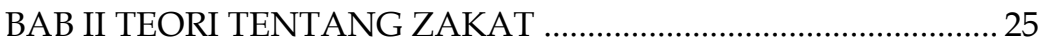

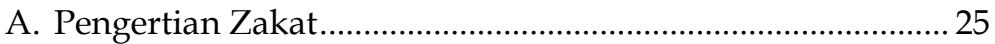

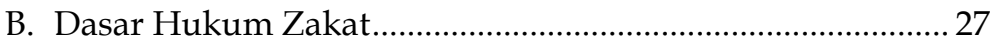

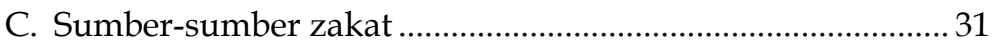

D. Golongan yang berhak menerima Zakat................................ 37

E. Pemberdayaan Zakat ........................................................... 40

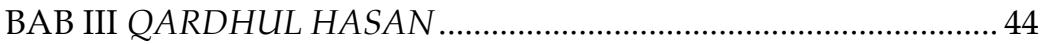

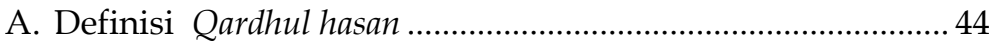

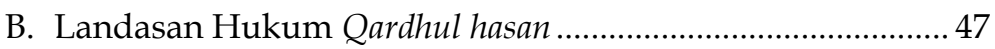

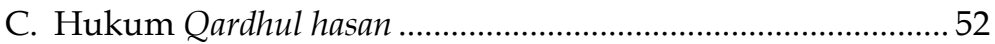

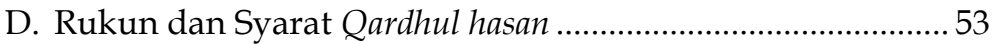

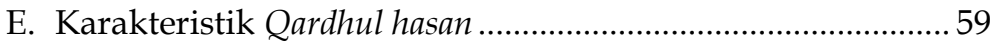

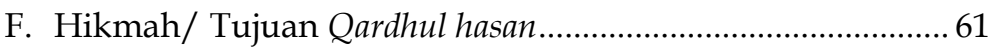

G. Waktu dan Tempat Pengembalian Qardhul hasan ................... 61

H. Aplikasi Qardhul hasan dalam Lembaga Keuangan

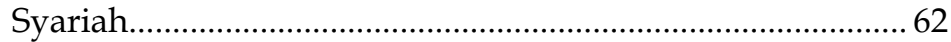

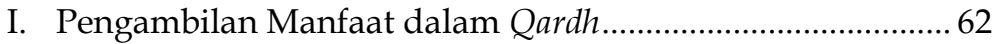

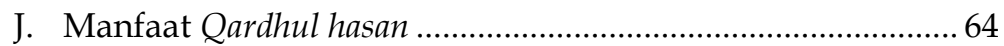

BAB IV QARDHUL HASAN DI BAITUL QIRADH BAZNAS ........66

A. Pelaksanaan Qardhul hasan di Baitul Qiradh BAZNAS Provinsi Sumatera Selatan. 
1. Proses Terbentuknya Baitul Qiradh BAZNAS Provinsi Sumatera Selatan...

2. Sumber Dana Qardhul hasandi Baitul Qiradh BAZNAS Provinsi Sumatera Selatan 68

3. Prosedur Pelaksanaan Akad Qardhul hasan di Baitul Qiradh BAZNAS Provinsi Sumatera Selatan

B. Perspektif Hukum Ekonomi Syariah tentang Pelaksanaan Qardhul hasan .....

C. Tinjauan Hukum Ekonomi Syariah Terhadap Pelaksanaan Qardhul hasan di Baitul Qiradh BAZNAS Provinsi Sumatera Selatan ...................................................92

1. Pelaksanaan Akad Qardhul hasan .......................................92

2. Infak dan Biaya Administrasi (Ujrah) ..................................99

3. Syarat Pihak yang memberi pinjaman (muqridh) ............102

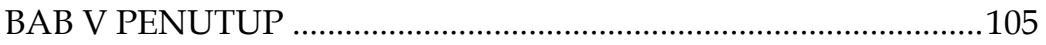

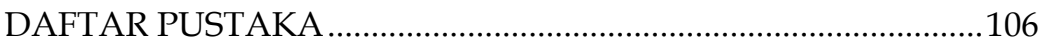

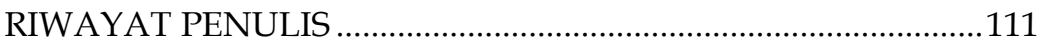




\section{PELAKSANAAN QARDHUL HASAN DALAM PENDISTRIBUSIAN ZAKAT DI BAITUL QIRADH BAZNAS}




\section{BAB I PENDAHULUAN}

\section{A. Kewajiban Zakat dalam Islam}

Telah menjadi sunnatullah bahwasanya manusia hidup saling tolong-menolong terhadap sesama. Sebagai makhluk sosial manusia menerima dan memberi bantuan pada orang lain untuk memenuhi hajat hidup dan mencapai kemajuan dalam hidupnya.

Allah telah memberikan kelebihan yaitu akal pikiran kepada manusia, dengan akal yang dapat mereka gunakan adalah untuk mengelola alam, sehingga manusia mendapatkan manfaat, baik bagi dirinya maupun masyarakat. Di bumi, manusia diberi tugas untuk mengelola alam dan meningkatkan kehidupan di dalamnya yaitu dengan cara saling tolong menolong, seperti yang kaya memberi bantuan kepada yang miskin, yang kuat memberi pertolongan kepada yang lemah, maka dari itu dengan keseimbangan dunia ini dapat tercapai. ${ }^{8}$ Zakat merupakan salah satu cara untuk mewujudkan prinsip tolong-menolong dan salah satu cara untuk mewujudkan keadilan sosial.

Kewajiban zakat dalam Islam memiliki makna yang sangat fundamental. Selain berkaitan dengan erat dengan aspek-aspek ketuhanan, juga ekonomi dan sosial. Di antara aspek-aspek ketuhanan (transedental) adalah banyaknya ayatayat al-qur'an yang menyebut masalah zakat, termasuk di antaranya 27 ayat yang menyandingkan kewajiban zakat dengan kewajiban shalat secara bersamaan. Bahkan Rasulullah pun menempatkan zakat sebagai salah satu pilar utama dalam menegakkan agama Islam.

${ }^{8}$ Farida Prihatini dkk, Hukum Islam Zakat dan Wakaf Teori dan Prakteknya di Indonesia,Cet 1, Penerbit Papas Sinar Sinanti dengan Badan Penerbit Fakultas Hukum Universitas Indonesia,2005, hal. 47-48 
Zakat adalah memberikan kadar harta tertentu kepada yang berhak menerimanya dengan syarat tertentu, seorang yang mengeluarkan zakat, berarti dia telah membersihkan diri, jiwa dan hartanya. Dia membersihkan jiwanya dari penyakit kikir, dan membersihkan hartanya dari hajat orang lain yang ada dalam hartanya itu. Orang yang berhak menerimanya pun akan bersih jiwanya dari penyakit dengki, iri hati terhadap orang yang mempunyai harta. Sedangkan dari aspek keadilan sosial, perintah zakat dipahami sebagai satu kesatuan sistem yang tak terpisahkan dalam pencapaian kesejahteraan sosial ekonomi dan kemasyarakatan. Zakat diharapkan dapat meminimalisir kesenjangan pendapatan antara orang kaya dan miskin. Di samping itu, zakat juga diharapkan dapat meningkatkan atau menumbuhkan perekonomian, baik pada level individu maupun pada level sosial masyarakat.

Islam memerintahkan kepada manusia untuk bekerja sama dalam segala hal, kecuali dalam perbuatan dosa kepada Allah atau melakukan aniaya kepada sesama makhluk, sebagaimana firman Allah dalam QS. Al Ma-'idah ayat $2:{ }^{9}$

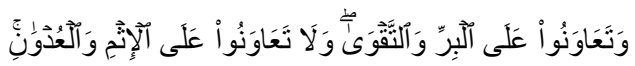

"Dan tolong-menolonglah kamu dalam (mengerjakan) kebajikan dan takwa, dan jangan tolong-menolong dalam berbuat dosa pelanggaran dan bertakwalah kamu kepada Allah, sesungguhnya Allah berat siksa-Nya". (Q.S. $5: 2)^{10}$

Perintah tolong menolong dalam kebaikan sesuai ayat yang telah dijelaskan di atas meliputi semua aspek kehidupan yakni sosial, budaya dan ekonomi. Dalam persoalan ekonomi khususnya yang berprinsip syari'ah juga bermacam-macam bahasannya antara lain syirkah, jual beli, gadai, utang piutang dan masih banyak lagi. Diantara jenis kerja sama dan tolong menolong yang telah membudaya di kalangan masyarakat

${ }^{9}$ Ismail Nawawi, Ekonomi Islam - Teori, Sistem, dan Aspek Hukum, Surabaya: CV Putra Media Nusantara, 2009, 51.

${ }^{10}$ Departemen Agama, al Qur'an dan Terjemahnya, 1992, 107. 
adalah pinjam meminjam dan utang-piutang. Bentuk kerjasama tersebut selain diwujudkan melalui lembaga keuangan bank maupun non bank juga diterapkan di BAZNAS.

Di Indonesia, Badan yang mengelola dana ZIS berkembang dan terus berupaya menjangkau kemiskinan dipelosok tanah air. Badan Amil Zakat Nasional (BAZNAS) Sumatera Selatan sebagai salah satu Badan Pengelola dana ZIS pun tergerak dalam penyaluran pada bentuk programprogram kemanusiaan di tanah air dan membantu mengentaskan kemiskinan dalam menciptakan kesejahteraan, salah satunya dengan cara pendistribusian zakat produktif yang dialokasikan pada Baitul Qiradh BAZNAS untuk diberdayakan.

Baitul Qiradh dalam arti bahasa adalah "Rumah Pinjaman" yang usaha pokoknya menghimpun dana dari pihak ketiga (anggota penyimpan) dan menyalurkan pembiayaan kepada usaha-usaha yang produktif dan menguntungkan.

Keberadaan Baitul Qiradh sebagai salah satu lembaga penyedia layanan keuangan mikro terhadap masyarakat kelas bawah. Baitul Qiradh telah mampu memainkan peranan penting dalam upaya pemberdayaan masyarakat untuk mengentaskan kemiskinan dan juga untuk mencapai taraf hidup yang sejahtera. Baitul Qiradh juga melakukan berbagai aktivitas keuangan dalam upaya memberikan pelayanan finansial terhadap masyarakat yang memiliki penghasilan yang kecil.11

Baitul Qiradh belum dapat dipayungi oleh ketentuan hukum yang jelas karena dalam peraturan hukum Indonesia yang dapat melakukan simpan pinjam adalah koperasi dan perbankan. Sehingga untuk saat ini Baitul Qiradh diarahkan dalam payung hukum koperasi. Selain untuk mensejahterakan anggotanya, Baitul Qiradh juga berupaya untuk memajukan

\footnotetext{
11 Alfafinance, Survey Lembaga Keuangan Mikro di Baitul Qiradh Nanggroe Baznas Madani (Online) akses tanggal 7 maret 2017 tersedia :https:/ /alfafinance.wordpress.com/2009/07/08/survey-lembaga-keuanganmikro-di-baitul-qiradh-nanggroe-baznas-madani-kelompok-8/
} 
kehidupan masyarakat kelas bawah untuk mencapai taraf hidup yang layak.

Salah satu bentuk pelayanan di Baitul Qiradh yaitu dengan cara tolong menolong melalui qardhul hasan (pinjaman kebajikan). Pihak yang meminjamkan dapat menerima imbalan namun tidak diperkenankan untuk dipersyaratkan di dalam perjanjian. qardhul hasan adalah pinjaman tanpa imbalan yang memungkinkan peminjam untuk menggunakan dana tersebut selama jangka waktu tertentu dan mengembalikan dalam jumlah yang sama pada akhir periode yang disepakati. Jika peminjam mengalami kerugian bukan karena kelalaiannya, maka kerugian tersebut dapat mengurangi jumlah pinjaman. ${ }^{12}$

Qardhul hasan selain di aplikasikan di Lembaga Keuangan Syariah juga di terapkan di BAZNAS (Badan Amil Zakat Nasional). BAZNAS adalah organisasi pengelola zakat yang dibentuk oleh pemerintah, yang terdiri dari unsur masyarakat dan pemerintah dengan tugas mengumpulkan, mendistribusikan dan mendayagunakan zakat sesuai dengan ketentuan agama. ${ }^{13}$

Berdasarkan hasil wawancara dengan pengurus BAZNAS Provinsi Sumatera Selatan, BAZNAS membentuk 5 buah Baitul Qiradh dan Sumber dana qardhul hasan pada masing-masing Baitul Qiradh berkisar antara Rp. 20.000.000,00 - Rp. 45.000.000,00 yang berasal dari dana ZIS yang dikumpulkan oleh BAZNAS Provinsi Sumatera Selatan dengan syarat ada pengajuan proposal terlebih dahulu. ${ }^{14}$

Pada pelaksanaan akad qardhul hasan yang ada di Baitul Qiradh BAZNAS Provinsi Sumatera Selatan, misalnya seorang peminjam (muqtaridh) mendapat pinjaman sebesar $\mathrm{Rp}$ 2.000.000,- dengan jangka waktu 20 bulan . Berdasarkan Akad yang berlaku dijelaskan sebagai berikut :

12 Muhammad dan Dwi Suwiknyo, Akuntansi Perbankan Syariah, Yogyakarta: Trustmedia, 2009, h. 69.

${ }^{13}$ Soemitra Andri, Bank dan Lembaga Keuangan Syariah, Jakarta: kencana, 2009, h. 419.

14 Wawancara dengan Bapak Hendra Praja selaku Kabid Pendistribusian dan Pendayagunaan tanggal 25 November 2016 
1. Pihak Kedua membayar pokok sebesar Rp. 100.000 (Seratus Ribu Rupiah) sesuai dengan jatuh tempo setiap bulannya.

2. Pihak kedua menyertakan uang sebesar Rp. 10.000,- tiap bulannya dengan rincian Rp. 5.000,- sebagai tabungan Rp. 5.000 ,- sebagai infaq.

Akad qardhul hasan yang sebenarnya bertujuan untuk membantu dan memberikan kemudahan kepada orang yang dalam kesusahan, sedangkan menurut Said Sabiq haram bagi yang memberikan bantuan untuk mengambil keuntungan apalagi mengekploitasi karena ini digolongkan riba. Dia akan menerima kembali sesuai dengan apa yang telah ia berikan, tidak lebih dari itu. ${ }^{15}$

\section{B. Gambaran Umum BAZNAS Provinsi Sumatera Selatan}

\section{Sejarah Berdirinya BAZNAS Prov. Sumatera Selatan}

Politik Hindia Belanda tidak melakukan campur tangan dalam masalah agama, kecuali untuk suatu kepentingan berlanjut hingga masa penjajahan Jepang sampai masa Indonesia merdeka. Politik Hindia Belanda ini tercantum melalui beberapa pasal dari "Indisce Stastsregeling", diantaranya pada pasal 134 ayat 2 yang mengarah pada Policy of religion neutrality. Konteks kepentingan penjajah tersebut dibentuk dalam ketertiban masjid, zakat dan fitrah, naik haji, nikah, talak, rujuk dan pengajaran agama Islam. Seperti tercantum dalam bijblad Nomor 1892 tanggal 4 Agustus 1893 yang berisi kebijakan Pemerintah Hindia Belanda untuk mengawasi pelaksanaan zakat dan fitrah yang dilaksanakan oleh para penghulu atau naib untuk menjaga dari penyelewengan keuangan. Kemudian pada bijblad Nomor 6200 tanggal 28 Februari 1905 berisi larangan bagi segenap pegawai

${ }^{15}$ Al-Kahlany dalam Syukri Iska, Sistem Perbankan Syariah di Indonesia, Yogyakarta : Fajar Media Press, 2012, hlm. 179 
pemerintahan maupun priyayi bumi putra turut campur dalam pelaksanaan zakat fithrah. ${ }^{16}$

Tradisi pengumpulan zakat oleh petugas-petugas jamaat urusan agama masih terus berlangsung hingga Indonesia merdeka. Perubahan untuk pengaturan zakat mengalami dinamika sejalan dengan peta perpolitikan di Tanah Air. Sehingga sampai tahun 1968 zakat dilaksanakan oleh umat Islam secara perorangan atau melalui kyai, guruguru ngaji dan juga melalui lembaga-lembaga keagamaan. Belum ada suatu badan resmi yang dibentuk oleh pemerintah untuk mengelola zakat, (kecuali di Aceh yang sudah diatur badan zakat sejak tahun 1959). ${ }^{17}$

Pasca 1968 adalah tahun yang sangat penting bagi sejarah pelaksanaan zakat di Indonesia, karena sejak tahun tersebut pemerintah mulai ikut serta menangani pelaksanaan zakat. Dasar intervensi pemerintah dari seruan Presiden dalam pidato peringatan Isra' Mi'raj di istana Negara pada tanggal 26 oktober 1968, dimana beliau menganjurkan pelaksanaan zakat secara lebih intensif untuk menunjang pembangunan Negara, dan Presiden siap menjadi amil zakat nasional. Seruan tersebut ditindaklanjuti dengan keluarnya Surat Perintah Presiden No. 07/PRIN/1968 tanggal 31 Oktober 1968 yang memerintahkan Alamsyah, Azwar Hamid, dan Ali Afandi untuk membantu Presiden dalam administrasi penerimaan zakat seperti dimaksud dalam seruan Presiden pada peringatan Isra' dan Mi'raj tanggal 26 Oktober 1968 tersebut. ${ }^{18}$

Upaya pemerintah untuk memaksimalkan pengumpulan dan pendayagunaan dana zakat dibuatlah aturan-aturan.Pada tanggal 23 September 1999 di awal Era

${ }^{16}$ Data Profil Badan Amil Zakat Nasional (BAZNAS) Provinsi Sumatera Selatan

${ }^{17}$ Data Profil Badan Amil Zakat Nasional (BAZNAS) Provinsi Sumatera Selatan

${ }^{18}$ Data Profil Badan Amil Zakat Nasional (BAZNAS) Provinsi Sumatera Selatan 
Reformasi di Republik ini, di bawah kepemimpinan Presiden BJ Habibie lahirlah Undang-Undang Nomor 38 Tahun 1999 tentang Pengelolaan Zakat. Undang-undang tersebut kemudian disusul dengan Keputusan Menteri Agama Nomor 581 Tahun 1999 tentang pelaksanaan Undang-Undang Nomor 38 tahun 1999 dan disempurnakan dengan Keputusan Menteri Agama Nomor 373 Tahun 2003 dan Keputusan Dirjen Bimas Islam dan Urusan Haji, Departemen Agama Nomor D/291/2000 tentang Pedoman Teknis Pengelolaan Zakat. ${ }^{19}$

Dalam Undang-undang tersebut antara lain disebutkan bahwa pengelolaan zakat dilakukan oleh Badan Amil Zakat yang dibentuk oleh Pemerintah (pasal 6). Pengelolaan zakat adalah kegiatan perencanaan, pengorganisasian, pelaksanaan dan pengawasan terhadap pengumpulan dan pendistribusian serta pendayagunaan zakat (pasal 1). Pengelolaan zakat tidak hanya terbatas pada harta zakat saja, namun juga termasuk pengelolaan infak, sedekah, hibah, wasiat, waris dan kafarat (pasal 13). ${ }^{20}$

Berdasarkan Perundang-undangan di atas, Badan Amil Zakat (BAZ) Provinsi Sumatera Selatan dibentuk dengan Surat Keputusan Gubernur Provinsi Sumatera Selatan tanggal 20 Juni 2001 Nomor: 352/SK/V/2001 dan Nomor : 404/SK/III/2001 Tanggal 23 Juli 2001 Tentang Pembentukan BAZ Provinsi Sumatera Selatan untuk masa bhakti 2001-2004 dan diperbaharui lagi Nomor 433/KPTS/V/2005 tanggal 12 Juli 2005 untuk masa bhakti 2005-2008; kemudian melalui Keputusan Gubernur Sumatera Selatan No. 269/Kepts/I/2009 untuk periode 2009-2012. Untuk meningkatkan pelayanan dibentuk Unit Pengumpul Zakat (UPZ) dengan tugas untuk melayani Muzakki dalam menyerahkan zakat, infak dan shadaqahnya. UPZ dibentuk di tiap Instansi/Lembaga Selatan

${ }^{19}$ Data Profil Badan Amil Zakat Nasional (BAZNAS) Provinsi Sumatera Selatan

${ }^{20}$ Data Profil Badan Amil Zakat Nasional (BAZNAS) Provinsi Sumatera 
Pemerintah, BUMN, BUMD, Perusahaan Swasta tingkat provinsi. $^{21}$

Dalam perkembangan selanjutnya pelaksanaan zakat di Indonesia tampak kecenderungan baru yang merupakan perubahan ciri dari pelaksanaan zakat tersebut. Pada tanggal 29 Mei 2002 Presiden Republik Indonesia meresmikan Silaturahmi dan Rapat Koordinasi Nasional ke I Badan Amil Zakat Nasional dan Lembaga Amil Zakat seluruh Indonesia di Istana Negara. Dalam pidatonya, Presiden menekankan agar Badan Amil Zakat baik ditingkat Nasional maupun Daerah, ataupun pengurus Lembaga Amil Zakat baik di tingkat nasional maupun daerah untuk tidak ragu-ragu bekerjasama dengan Menteri Agama, Menteri Keuangan, Menteri Negara Koperasi dan usaha Kecil dan Menengah maupun menteri terkait lainnya.

BAZNAS Propinsi Sumatera Selatan telah memiliki perangkat Perundang-undangan berupa Peraturan Daerah (PERDA) Provinsi Sumatera Selatan Nomor 6 Tahun 2005 tentang Pengelolaan Zakat.Badan Amil Zakat Provinsi Sumatera Selatan pertama kali berdiri dan mulai beroperasi pada tanggal 23 Juli 2001. Berdirinya Badan Amil Zakat Provinsi Sumatera Selatan ini diresmikan Oleh Gubernur Sumatera Selatan yang pada waktu itu dijabat oleh Rosihan Arsyad.22

Badan Amil Zakat Nasional (BAZNAS) Sumatera Selatan pertama kali beralamat di Kampus Jln. Bidar Blok B No. 22 Lorok Pakjo Palembang. Namun pada tahun 2004 Baznas Sumatera Selatan mendapatkan bantuan gedung olehGubernur Sumatera Selatan yang beralamat di Jln. Kapten A. Riva'i No. 259 Palembang. Dan sudah pindah lagi sekarang dengan alamat kantor Jl. Jendral Sudirman No. Selatan

${ }^{21}$ Data Profil Badan Amil Zakat Nasional (BAZNAS) Provinsi Sumatera

22Data Profil Badan Amil Zakat Nasional (BAZNAS) Provinsi Sumatera Selatan 
7490 Km. 2,5 Palembang - Sumatera selatan Telp/Fax : 0711360966.23

\section{Fungsi dan Tugas Pokok BAZNAS Provinsi Sumatera Selatan}

\section{a. Dewan pertimbangan}

1) Dewan Pertimbangan bertugas memberikan pertimbangan, fatwa, saran dan rekomendasi tentang pengembangan hukum dan pemahaman mengenai pengelolaan zakat;

2) Mengeluarkan fatwa syari'ah baik diminta maupun tidak berkaitan dengan hukum zakat yang wajib diikuti oleh pengurus Badan Amil Zakat;

3) Memberikan pertimbangan, saran dan rekomendasi kepada Badan Pelaksana dan Komisi Pengawas;

4) Menampung, mengolah dan menyampaikan pendapat umat tentang Pengelolaan Zakat.

\section{b. Komisi Pengawas}

1) Komisi Pengawas bertugas melaksanakan pengawasan internal atas operasional kegiatan yang dilaksanakan;

2) Mengawasi pelaksanaan rencana kerja yang telah disahkan;

3) Mengawasi pelaksanaan kebijakan-kebijakan yang telah ditetapkan;

4) Mengawasi operasional kegiatan yang dilaksanakan Badan Pelaksana, yang mencakup pengumpulan pendistribusian dan pendayagunaan.;

5) Melakukan pemeriksaan operasional dan pemeriksaan syari'ah dan peraturan perundangundangan;

6) Menunjuk akuntan publik.

${ }^{23}$ Data Profil Badan Amil Zakat Nasional (BAZNAS) Provinsi Sumatera 


\section{c. Badan Pelaksana}

1) Merumuskan pokok - pokok kebijaksanaan pelaksanaan pengumpulan dan pendayagunaan zakat;

2) Menyusun rencana dan program operasional serta petunjuk pelaksanaan pengumpulan zakat;

3) Melaksanakan pengawasan dan koordinasi seluruh kegiatan pelaksanaan pengumpulan zakat, termasuk auditing administrasi keuangan.

4) Membentuk Unit Pengumpul Zakat (UPZ) pada Instansi/Lembaga dan Perusanaan Swasta yang berkedudukan di Ibukota provinsi.

Dalam melaksanakan tugasnya, BAZ Provinsi Sumatera Selatan bertanggung jawab kepada Gubernur Provinsi Sumatera Selatan.

\section{Visi dan Misi BAZNAS Provinsi Sumatera Selatan}

\section{Visi:}

Menjadi pusat pengumpulan dan pendayagunaan zakat, infaq dan shadaqah untuk pemberdayaan dan kesejahteraan umat di Indonesia. ${ }^{24}$

\section{Misi:}

a. Melaksanakan pengumpulan zakat, Infaq dan Shadaqah di Sumatera Selatan secara proaktif;

b. Mendistribusikan dana zakat, Infaq dan Shadaqah yang telah terkumpul kepada mustahik secara proporsional dan memperhatikan skala prioritas;

c. Mendayagunakan dana zakat, Infaq dan Shadaqah secara produktif untuk kemaslahatan dan pemberdayaan ekonomi umat;

d. Melaksanakan kajian untuk pengembangan dan peningkatan kualitas pengelolaan zakat, Infaq dan Shadaqah.

${ }^{24}$ Data Profil Badan Amil Zakat Nasional (BAZNAS) Provinsi Sumatera 


\section{Tujuan, Sasaran dan Asas Pengelolaan ${ }^{25}$}

\section{a. Tujuan}

1) Meningkatkan efektivitas dan efesiensi pelayanan dalam pengelolaan zakat; dan

2) Meningkatkan manfaat zakat untuk mewujudkan kesejahteraan masyarakat dan penanggulangan kemiskinan.

\section{b. Sasaran}

Sasaraan yang ingin dicapai dalam periode kepegurusan ini diarahkan kepada peningkatan kesadaran berzakat, pendistribusian yang proporsional dan mengacu kepada kemashlahatan umum, peningkatan tarap ekonomi umat, dan peningkatan profesionalisme BAZNAS dalam mengelola zakat.

\section{c. Asas Pengelolaan}

Adapun pengelolaan zakat berasaskan:

1) Syariat Islam (pengelolaan zakat dilakukan sesuai dengan syariat Islam);

2) Amanah (pengelola zakat harus dapat dipercaya);

3) Kemanfaatan (pengelolaan zakat dilakukan untuk memberikan manfaat yang sebesar-besarnya bagi mustahik);

4) Keadilan (pengelolaan zakat dalam pendistribusiannya dilakukan secara adil);

5) Kepastian hukum (pengelolaan zakat terdapat jaminan kepastian hukum bagi mustahik dan muzaki);

6) Terintegrasi (pengelolaan zakat dilaksanakan secara hierarkis dalam upaya meningkatkan pengumpulan, pendistribusian, dan pendayagunaan zakat); dan

7) Akuntabilitas (dapat dipertanggungjawabkan dan diakses oleh masyarakat). 


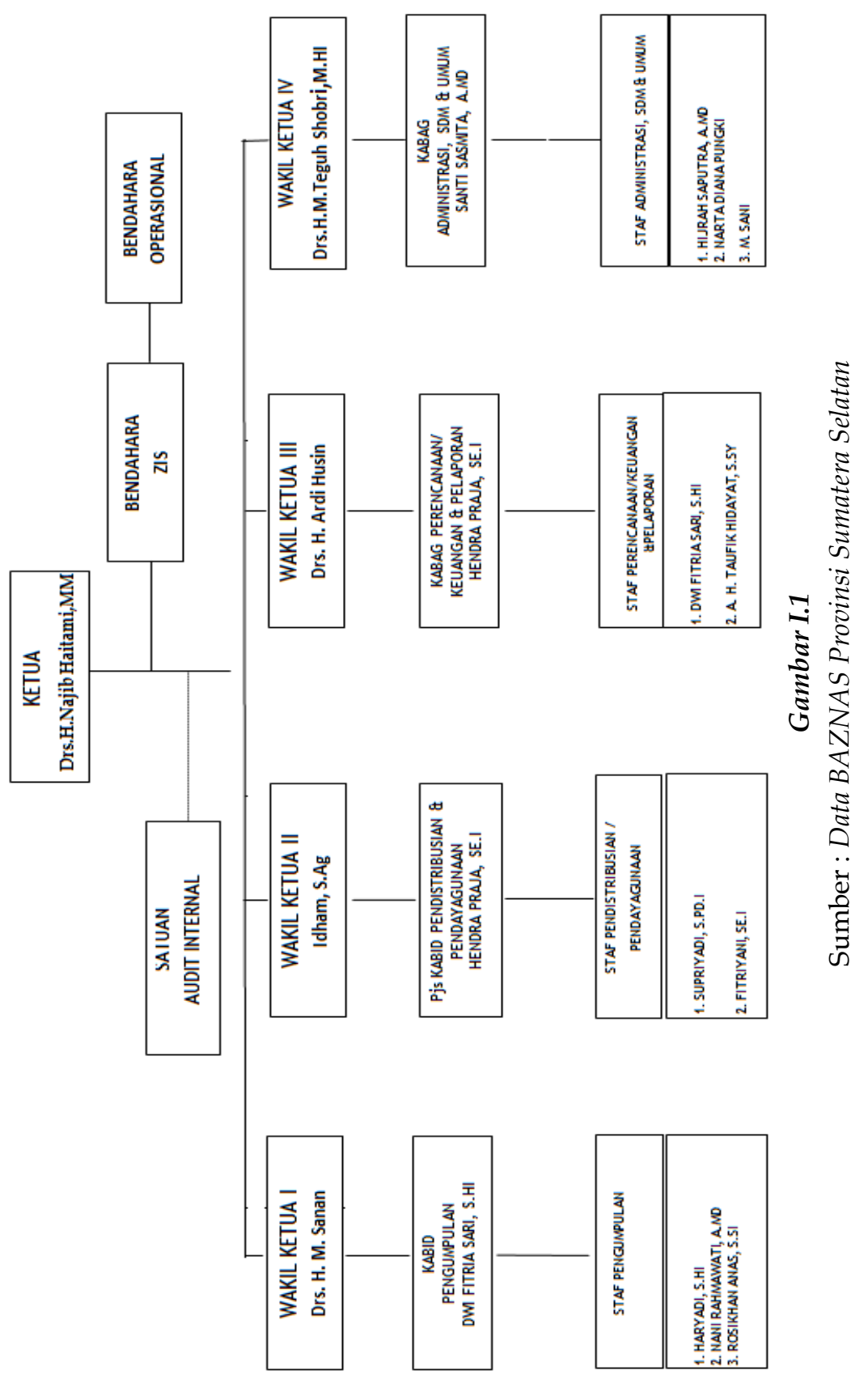




\section{Strategi Badan Amil Zakat Nasional (BAZNAS) Sumatera Selatan ${ }^{26}$}

Untuk mencapai tujuan dan sasaran, BAZNAS Provinsi Sumatera Selatan membuat kebijakan dan program.

a. Untuk mewujudkan pengelolaan zakat yang terintegrasi dalam merealisasikan potensi zakat dan mengoptimalkan peran BAZNAS di Sumatera Selatan perlu membangun visi bersama dan penataan infrastruktur kelembagaan zakat.

b. Standarisasi system kelembagaan, keamilan, perencanaan dan penganggaran, pengumpulan, pendistribusian dan pendayagunaan, standarisasi pengendalian, pelaporan dan pertanggung jawaban, standarisasi informasi manajemen dan standarisasi sumberdaya manusia, serta system pengawasan, sehingga Badan Amil Zakat Nasional di Sumatera Selatan menjadi yang terunggul dan termodern di Indonesia.

c. Muzakki-oriented service system dan mustahik-oriented service system

d. Akuntabilitas organisasi dan pelayanan zakat

e. Menerapkan system manajemen kerja yang nyaman, produktif dan terintegrasi.

f. Bekerjasama dengan seluruh komponen masyarakat; seperti organisasi masyarakat, organisasi profesi dan tokoh masyarakat/alim ulama untuk meningkatkan kesadaran masyarakat berzakat dan meningkatnya hasil pengumpulan ZIS yang optimal.

g. Melakukan inovasi dan pengembangan teknik-teknik pengumpulan ZIS dan penyalurannya, sehingga kepercayaan masyarakat terhadap BAZNAS semakin meningkat.

${ }^{26}$ Data Badan Amil Zakat Nasional (BAZNAS) Provinsi Sumatera Selatan 